\title{
Molecular organic geochemical evidence for the Ediacaran ocean oxidation in South China
}

\section{CHUNJIANG WANG}

China University of Petroleum (Beijing)

Presenting Author: wchj333@126.com

Ocean oxygen concentration is regarded as an important factor controlling the origin and evolution of animals ${ }^{[1]}$. The marine redox condition of the Ediacaran Doushantuo Formation in South China has been widely studied ${ }^{[2,3,4]}$. Sulfur-containing aromatic compounds such as dibenzothiophenes (DBT) have been used in paleoenvironmental evaluation for many years ${ }^{[5,6]}$. Its thermal stability makes it useful even for over-mature rocks. In this paper, we present some interpretation for the Ediacaran Doushantuo oxidation based on organic geochemical results from Weng'an, Miaohe and Jiulongwan section in South China.

Combined organic geochemical analysis reveals that the hydrocarbons in the Doushantuo $\mathrm{Fm}$ are indigenous. At Jiulongwan section, the DBT index varies in a three-phase temporal trend: it is very low in Doushantuo Member II, then it increases evidently in Member III and rises to highest values in Member IV (an order of magnitude more than the Member II). The extremely low DBT concentration in Member II could provide a robust evidence for a ferruginous ocean. On the contrary, the high DBT content in Member IV could be the results of higher sulfide production in deep water and sediments, triggered by high marine sulfate concentration contributed by the Ediacaran oxidation.

This DBT stratigraphic variation highly mirror the S-isotopic composition of pyrite, strongly indicating that the DBT concentration is closely related to ocean sulfate concentration. The transition from ferruginous to oxic condition ocurred during Member III. The DBT record does not match the Doushantuo negative $\mathrm{C}$-isotope excursion around Member IIIb-IIIc transition, probably because of the organic-lean carbonates, deposited in the oxic condition, could not have recorded the true DBT value.

At Weng'an section, the phosphate-rich shale interval in the middle Doushantuo Fm is very rich in DBTs, indicating a sulfide-rich deep water condition, caused by higher primary production and ocean oxidation.

References

[1] Lyons et al (2014), Nature 506, 307-315.

[2] Canfield et al (2007), Science 315, 92-95.

[3] Li et al (2010), Science 328, 80-83.

[4] Sahoo et al (2016), Geobiology 14, 457-468.

[5] Hughes et al (1995), GCA 59, 3581-3598.

[6] Wang \& Visscher (2007), PPP 252, 291-303. 